Człowiek chory i umierający. Możliwości wsparcia i formy pomocy, red. J. Stala, Kraków 2014, Wydawnictwo Naukowe UPJPII, s. 265-278. http://dx.doi.org/10.15633/9788374384117.18

Bernadetta Eacheta*

Stacja Opieki Caritas Archidiecezji Krakowskiej

\title{
ZROZUMIENIE STAROŚCI
}

\section{Starość i starzenie się}

Czym jest starość i kiedy się rozpoczyna? Faktu tego nie sposób ustalić z kalendarzową dokładnością. Zależy to od różnorodnych czynników: zdrowia psychicznego i fizycznego, temperamentu, stylu i warunków życia. Nie ma zatem ustalonej prawidłowości w przebiegu ludzkiego życia. Jedno jest pewne i jednakowe u wszystkich, a mianowicie to, że nagle lub niespostrzeżenie starość nastąpi w pewnym okresie życia ludzkiego. Jest to fakt konieczny i nieubłagany ${ }^{1}$.

Starość jako zjawisko należy analizować w powiązaniu ze starzeniem się jako procesem, dostrzegając jednocześnie biologiczne aspekty starzenia się osobniczego oraz ich demograficzne, ekonomiczne i społeczne konsekwencje, znajdujące wyraz w zjawisku starzenia się ludności. Obydwa te pojęcia mają charakter interdyscyplinarny, co skutkuje różnorodnością definicji proponowanych przez poszczególnych specjalistów, reprezentujących różne dziedziny wiedzy.

Najczęściej starość określa się jako okres życia ustroju następującego po wieku dojrzałym, który charakteryzuje się obniżeniem funkcji życiowych i szeregiem zmian morfologicznych w poszczególnych układach i narządach ${ }^{2}$.

Przegląd literatury wskazuje na brak podstaw do stwierdzenia, że starość rozpoczyna się zawsze $\mathrm{w}$ chwili przekroczenia pewnego wieku, $\mathrm{z}$ czego wynika wielość podziałów i ustaleń dotyczących początku tego okresu. A oto niektóre z nich.

Według ustaleń Światowej Organizacji Zdrowia (WHO) przyjmuje się podział na:

- fazę wieku starszego od 60 do 75 lat,

- fazę wieku starego od 75 do 90 lat,

- fazę głębokiej starości - ponad 90 lat $^{3}$.

* BERNADETTA ŁACHETA - pielęgniarka, kierownik Stacji Opieki Caritas Archidiecezji Krakowskiej.

1 Por. S. Karczmarek, Rozważania o życiu ludzkim, Warszawa 1997, s. 56.

2 Por. K. Wiśniewska-Roszkowska, Gerontologia dla pracowników socjalnych, Warszawa 1982.

3 Por. N. Wolański, Rozwój biologiczny człowieka, Warszawa 1979, s. 79-80. 
Rozpiętość najniżej i najwyżej przeprowadzonych granic między wiekiem dojrzałym a starością jest znaczna. Politolog niemiecki Ludwig Aschoff twierdził, iż starość rozpoczyna się w 45 roku życia. Gerontologia radziecka uznawała za początek starości 80 rok życia ${ }^{4}$.

Maria Susułowska rozpatruje pojęcie starości z trzech punktów widzenia:

- liczby przeżytych lat (wiek metrykalny, kalendarzowy),

- zmian biologicznych w organizmie (wiek biologiczny),

- zmian psychicznych (wiek psychologiczny).

Gerontolodzy różnie podchodzą do ustalenia granic pomiędzy wiekiem dojrzałym a starością. Jako początek starości literatura określa najczęściej wiek rozpoczynający się po ukończeniu 61 roku życia. Jest to okres związany z ustaniem obowiązków zawodowych i przejściem na emeryturę.

Życie ludzkie składa się z szeregu okresów, na które składają się pełnione role społeczne, znaczące wydarzenia, zadania psychiczne i postawy. Wydaje się zatem słuszne, aby wskazać kilka rodzajów periodyzacji życia ludzkiego, dokonanych przez autorów opierających się na różnych kryteriach, co pozwoli bliżej przyjrzeć się okresom twórczym życia ludzkiego a także towarzyszącym im postawom ze zwróceniem szczególnej uwagi na ostatni etap życia ludzkiego - starości.

Starzenie się człowieka jest zjawiskiem naturalnym, rozciągniętym w czasie od niełatwego do ustalenia początku aż do naturalnej śmierci. O ile zakończenie starzenia określone jest momentem śmierci fizjologicznej, to jego początek wyznaczany jest mniej precyzyjnie - najczęściej między 35 a 45 rokiem życia, kiedy to zaczynają pojawiać się „,znamiona starości” pogarszające możliwości pełnienia przez człowieka jego ról życiowych.

Literatura wskazuje szereg klasyfikacji, według których, życie ludzkie dzielono na różne okresy w zależności od celów, którym ten podział służył. Gerontolodzy skupiają uwagę na ostatnim okresie życia człowieka, jakim jest starość. W cyklu życiowym ${ }^{5}$ dorosłego ujętym w siedem faz, na uwagę zasługują dwa ostatnie stadia przypadające na okres starości i starzenia się człowieka. A oto jak przedstawia poszczególne fazy:

- Stadium opuszczenia domu rodzinnego (w wieku 18-22 lat),

- Faza wejścia w świat ludzi dorosłych (między 23-28 rokiem życia),

- Okres dążenia do stabilizacji życiowej (w wieku 29-34 lat),

- Stadium tożsamości osobowościowej (między 37 a 42 rokiem życia),

- Okres przełomu (między 45 a 55 rokiem życia),

\footnotetext{
4 Por. Z. Szarota, Wielofunkcyjna działalność domów pomocy społecznej dla osób starszych, Kraków 1998, S. 123.

5 Por. A. Zych, Człowiek wobec starości. Szkice z gerontologii społecznej, Katowice 1999, s. 162.
} 
- Okres tolerancji (w wieku 57-64 lat),

- Faza refleksji nad życiem (w wieku 67 lat i powyżej).

Fazy te występują po sobie w dość regularnej kolejności, aczkolwiek czas ich trwania nieznacznie się różni. W dwóch ostatnich stadiach zostały wyróżnione następujące wydarzenia znaczące:

- możliwą utratę małżonka,

- możliwość pojawienia się problemów zdrowotnych,

- przygotowanie się do okresu spoczynku,

- stan spoczynku,

- pogorszenie się stanu zdrowia,

- zmianę sytuacji finansowej,

- śmierć małżonka.

W okresie tolerancji wzrasta rola małżonka, pojawia się także większa akceptacja ja. W okresie refleksji nad życiem pojawiają się typowe postawy dla wieku powyżej 67 lat. A oto jak charakteryzowane są te postawy:

- postawa retrospektywna: charakteryzująca się przeglądem życiowych dokonań,

- postawa prospołeczno-afiliatywna, która cechuje się chęcią dzielenia z innymi codziennych wydarzeń i związanych z nimi radości i kłopotów,

- postawa działania na rzecz rodziny: największą wartością jest rodzina,

- postawa tanatocentryczna: myśl o śmierci jako o nowej formie istnienia.

Powyższe podziały obejmują okresy, które występują po sobie w dość regularnej kolejności. Każdy z podziałów wskazuje różny czas trwania poszczególnych okresów, pojawiają się też nowe elementy, które wzbogacają lub modyfikują poprzednie. Klasyfikacje te są oparte na faktach psychologicznych, biologicznych i społecznych. Rozwój medycyny spowodował wydłużanie poszczególnych okresów życia ludzkiego. Znamienne dla końca XX wieku i początku XXI jest przedłużanie okresu młodości i coraz późniejsze zakładanie rodziny. Przedłuża się zatem wiek rozwojowy do około 35 roku życia. Okres twórczy (produkcyjny) również ulega wydłużeniu. Fakt ten jest związany z poszerzeniem granicy wieku zatrudnienia i wydłużeniu aktywności ekonomicznej zarówno kobiet jak i mężczyzn.

Proces starzenia się polega na powolnym i stopniowym obniżaniu się odporności organizmu na choroby i urazy, na które człowiek jest narażony w ciągu życia. Nasuwają się, zatem kolejne pytania: co dzieje się w organizmie ludzkim w miarę upływu lat, jakie procesy powodują nieuchronny, postępujący proces starzenia się człowieka?

Starość należy rozpatrywać, w co najmniej trzech aspektach:

- biologicznym,

- psychologicznym,

- społecznym. 
Rozpoczynając od perspektywy biologicznej. Można powiedzieć, że początki naukowej gerontologii sięgają XVI wieku. Prekursorem w tej dziedzinie był filozof angielski Francis Bacon (1561-1626). F. Bacon kierując się przedmiotem badań dokonywał podziału nauk na nauki o przyrodzie i nauki o człowieku. F. Bacon głosił, iż „poprzez systematyczne badanie procesów starzenia się można będzie wykryć przyczyny starości”. Uważał, że na proces starzenia wywiera ogromny wpływ niehigieniczny tryb życia, który określał jako „niehigieniczne praktyki”.

Podobne poglądy głosili inni ówcześni uczeni. Ilia Mieczników głosił tezę o zatruciu organizmu, który nie potrafi radzić sobie z wydalaniem toksyn jako przyczynę starzenia się i starości. Tę samą tezę odnosił do przyczyn przedwczesnego starzenia i zgonów. Wybitna uczona Olha Bogomolets przyczyn starzenia doszukiwała się w zmianach dokonujących się w tkance łącznej. Obecny rozwój gerontologii pozwala na wyodrębnienie wielu czynników mających wpływ na proces starzenia. Należą do nich czynniki psychologiczne, społeczne a także choroby ${ }^{6}$.

Organizm ludzki zbudowany jest z ogromnej liczby komórek. Stanowią one podstawę budulcową narządów wewnętrznych i układów. W trakcie życia człowieka, komórki są wymieniane na nowe. W miarę upływu życia proces wymiany komórek ulega spowolnieniu, a liczba komórek zmniejsza się. Komórki są poddane działaniu szeregu czynników, powodujących ich uszkodzenia. Zmniejsza się także zawartość wody w komórce, co powoduje zaburzenia pracy organów komórkowych. Spowolnieniu ulega także metabolizm komórkowy. Skutkiem jest odkładanie w narządach i tkankach cholesterolu, wapnia i lipofucyny - barwnika starczego.

Ubytki w masie mięśniowej, kostnej oraz tkance łącznej powodują obniżenie masy ciała. Zmniejszeniu ulega także objętość wody w organizmie. Zmianom podlega także wygląd skóry, która staje się sucha, mało elastyczna, cienka i szorstka. Pojawiają się zmarszczki. Zmiany w funkcjonowaniu zmysłów spowodowane są starzeniem się mózgu i degeneracją komórek odpowiedzialnych za tę funkcję. Zmiany w narządzie wzroku powodują upośledzenie widzenia. Z wiekiem pojawia się także niedosłuch i problemy z rozpoznawaniem zapachów. Występuje także pogorszenie rozpoznawania smaków. Z kolei zmiany w układzie sercowo-naczyniowym polegają na zmianach w układzie naczyń krwionośnych. Powoduje to wiele groźnych dla życia schorzeń jak zawał mięśnia sercowego lub mózgu. Zaburzenia pracy układu odpornościowego powoduje zwiększoną częstotliwość zachorowań. Obserwuje się również zaburzenia układu nerwowego. Człowiek stary ma kłopoty z koncentracją i skupieniem się na kilku rzeczach jednocześnie ${ }^{7}$.

\footnotetext{
6 Por. J. Piotrowski, Miejsce człowieka starego w rodzinie i społeczeństwie, Warszawa 1973, s. 56.

7 Por. A. Kowalewska, A. Jaczewski, K. Komosińska, Problemy wieku starczego, w: Seniorzy w rodzinie, instytucji i społeczeństwie, red. A. Fabiś, Sosnowiec 2005, s. 79.
} 
Obecnie obserwuje się wzrost liczby ludności w wieku starczym, a coraz więcej osób dożywa 100 lat. Przegląd literatury wskazuje, iż uczeni od wielu lat zgłębiają tajemnice procesu starzenia się organizmu ludzkiego. Starzenie się jest procesem naturalnym, polegającym na zmniejszeniu aktywności organizmu.

Scharakteryzowane w perspektywie biologicznej zmiany zachodzące w organizmie, są niejednokrotnie przyczyną upośledzenia sprawności fizycznej i wielu chorób. Przedmiotem uwagi społeczeństwa jest opóźnianie procesu starzenia poprzez propagowanie działań profilaktycznych. Realizacja owych działań to aktywny tryb życia, zdrowe odżywianie, eliminacja hałasu i stresu. Starość i związana z nią niesprawność fizyczna powoduje degradację społeczną ludzi starych. Problemy te stawiają przed społeczeństwem stworzenie optymalnych warunków pomocy instytucjonalnej i środowiskowej.

Patologię wieku starczego cechuje wielochorobowość. Oznacza to, iż rzadko występuje tylko jedna jednostka chorobowa. Przeważają choroby przewlekłe, o wieloletnim przebiegu. Najczęściej występującą chorobą wieku starczego jest miażdżyca, której istotą jest zwężenie światła tętnic przez złogi cholesterolu i wapnia. Powikłaniem miażdżycy jest pogorszenie ukrwienia narządów i tkanek, co powoduje przyśpieszenie procesu starzenia. $\mathrm{W}$ drugiej połowie życia powikłania miażdżycy stają się przyczyną wielu groźnych a często śmiertelnych chorób. Należą do nich zawał serca, udar mózgu, zator tętniczy, niewydolność serca i nerek oraz otępienie starcze ${ }^{8}$.

Starzenie w perspektywie psychologicznej oznacza zmiany, jakie pojawiają się pod wpływem czasu w osobowości, życiu emocjonalnym i duchowym człowieka. Proces ten przebiega pod wpływem zmian biologicznych zachodzących w całym organizmie człowieka, a zwłaszcza w mózgu. Zaburzenia w fizjologii pracy mózgu powodują osłabienie funkcji postrzegania, słuchu i wzroku. Powoduje to utrudniony kontakt ze światem zewnętrznym. Pojawiają się także zaburzenia pamięci krótkotrwałej oraz spowolnienie czasu reakcji. W okresie starości człowiek rozumie otaczający go świat często przez pryzmat swoich doświadczeń, z drugiej strony utrudniony kontakt ze światem spowodowany jest zaburzeniem fizjologii pracy mózgu. Konsekwencją tego jest poczucie osamotnienia i zawężenie kręgu zainteresowań. Częstym objawem starzenia się jest wzmożona drażliwość, zmienność nastroju, płaczliwość lub oziębłość uczuciowa. Objawy te są wynikiem zmniejszonej zdolności przystosowawczej do zmian zachodzących w otoczeniu?.

Zmiany zachodzące w mózgu w procesie starzenia powodują szereg zaburzeń, z którymi starszy człowiek nie zawsze potrafi sobie poradzić. Jest to nowy etap

8 Por. K. Wiśniewska-Roszkowska, Starość a przebieg chorób, w: Encyklopedia seniora, Warszawa 1986, s. 251.
9 Por. A. Kowalewska, A. Jaczewski, K. Komosińska, Problemy wieku starczego..., dz. cyt., s. 173. 
w życiu człowieka. Zmiany w narządach wzroku i słuchu często powodują alienację ludzi starych oraz pozbawienie ich relacji społecznych ze względu na swe upośledzenia. W konsekwencji prowadzi to do wycofania i depresji.

Przystosowanie się do tego etapu wymaga wiele zrozumienia ze strony najbliższych i społeczeństwa. Najważniejszą rolę powinna spełniać rodzina, gdyż nawet najlepsza opieka stacjonarna i troska zatrudnionego personelu nie jest $\mathrm{w}$ stanie zastąpić ciepła rodzinnego.

Proces starzenia jest zależny $\mathrm{w}$ dużym stopniu, od sposobu, w jaki człowiek będzie pełnił nowe role społeczne, jaka będzie jego pozycja w rodzinie oraz od postaw wobec ludzi starych panujących w społeczeństwie. Ważna jest również postawa, jaką przyjmie człowiek wobec starości. Zdaniem Jeana Vaniera ${ }^{10}$ można zaobserwować dwa sposoby starzenia. Pierwszy sposób charakteryzuje ludzi, którzy żyją wspomnieniami, są nastawieni krytycznie do wszystkiego i wszystkich, przez co pozostają smutni i samotni. Drudzy, mając świadomość swoich ograniczeń, próbują w tym okresie odnaleźć się i żyć pełnią życia.

Starzenie społeczne jest zależne zarówno od człowieka, który znajduje się w okresie starości, jak i środowiska społecznego. Ważną rolę odgrywają role rodzinne pełnione w okresie starości. Najczęściej jest to rola babci i dziadka. Pomoc w wychowywaniu wnuków pozwala czuć się potrzebnym i użytecznym. Szerokie kontakty z rówieśnikami, hobby dają możliwość miłego spędzenia czasu i pozwalają na rozwój zainteresowań. W naszym społeczeństwie obserwuje się obniżenie pozycji społecznej człowieka starego jako osoby niepracującej zawodowo i utrzymującej się najczęściej ze skromnej emerytury. Starzenie się społeczeństwa wymaga kształtowania odpowiednich postaw wobec starości wykwalifikowanej kadry psychologów, pedagogów i socjologów oraz szeregu działań socjalnych. Pozytywne kreowanie obrazu starości jest konieczne, aby ludzie starsi mogli godnie przeżyć ostatni etap swojego życia.

\section{Miejsce i rola ludzi starszych w społeczeństwie}

Barbara Szatur-Jaworska wymienia najważniejsze role społeczne ludzi starych i omawia sposób ich pełnienia ${ }^{11}$ :

- role zawodowe,

- role rodzinne,

- role sąsiedzkie i towarzyskie,

\footnotetext{
${ }^{10}$ Por. A. Kowalewska, A. Jaczewski, K. Komosińska, Problemy wieku starczego..., dz. cyt., s. 173.

${ }^{11}$ Por. B. Szatur - Jaworska, Ludzie starzy i starość w polityce społecznej, Warszawa 2001, s. 49.
} 
- rola członka wspólnoty religijnej,

- rola użytkownika czasu wolnego.

Role zawodowe - po osiągnięciu wieku emerytalnego część osób starszych nie decyduje się na przejście na emeryturę i nadal kontynuuje role zawodowe. W Polsce najwięcej takich osób obserwuje się wśród rolników indywidualnych, wśród twórców i osób wykonujących wolne zawody a także wśród pracowników nauki. Niektórzy emeryci podejmują nowe obowiązki zawodowe.

Role rodzinne - to przede wszystkim zmiany w życiu rodzinnym mężczyzn, którzy więcej czasu poświęcają wnukom, a także aktywności w obrębie gospodarstwa domowego.

Role sąsiedzkie i towarzyskie - najbardziej intensywnie przebiegają w pierwszych latach po przejściu na emeryturę. Są szczególnie preferowane przez mężczyzn, osoby dobrze wykształcone i samotne.

Rola członka wspólnoty religijnej - w wymiarze społecznym realizacja tej roli wiąże się z udziałem w praktykach religijnych. Sprzyja nawiązywaniu nowych kontaktów społecznych, tworzeniu grup samopomocowych wśród członków grup wspólnot wyznaniowych.

Rola użytkownika czasu wolnego - na ogół sprowadza się do uczestnictwa w kulturze i innych formach wypoczynku. Uczestnictwo osób starszych w kulturze najczęściej sprawdza się do domowych form „konsumpcji kulturalnej”. Czas wolny przeznaczony jest na czytelnictwo - głównie prasy, słuchanie radia i oglądanie telewizji. Aktywne formy wypoczynku zmniejszają bierność i izolację ludzi starych. Najczęściej preferowaną formą wypoczynku są spacery. Cześć osób starych uprawia sport, pracuje na działce lub opiekuje się zwierzętami.

Późny wiek dojrzały to okres wielu wyzwań, jakie niesie ze sobą starość. Wyzwania te, to przede wszystkim umiejętność dostosowania się do zmian związanych z wiekiem. Podjęcie nowych ról społecznych w związku z przejściem na emeryturę, przystosowanie się do sytuacji śmierci współmałżonka, pogorszenie stanu zdrowia i sprawności fizycznej stanowią główne problemy ludzi starych. Przystosowanie do nowej rzeczywistości zależy w dużej mierze od osobowości człowieka, która różni się u poszczególnych osobników.

A. Zych wyróżnia pięć różnych postaw ludzi starych. Tak charakteryzuje kolejne postawy ${ }^{12}$ :

- Postawa konstruktywna. Człowiek, u którego dominuje taka postawa jest wewnętrznie zrównoważony, charakteryzuje go podobny nastrój i dające mu satysfakcję udane kontakty z ludźmi. Potrafi być krytyczny w stosunku

\footnotetext{
${ }^{12}$ Por. A. Zych, Człowiek wobec starości..., dz. cyt., s. 139.
} 
do siebie, jednocześnie będąc tolerancyjnym w stosunku do innych. Akceptuje własną wartość oraz fakt przejścia na zasłużoną emeryturę. Posiada optymistyczny stosunek do życia, a konieczność śmierci przyjmuje ze spokojem. Jego bilans życiowy jest dodatni, dzięki czemu z ufnością liczby na pomoc otoczenia.

- Postawa zależności. Jest charakterystyczna dla osób wykazujących bierność i zależność od innych. Są to ludzie ulegli wobec partnera lub dziecka, nie mający zbyt wygórowanych aspiracji życiowych, w związku z czym chętnie wycofują się z aktywności zawodowej. Środowisko rodzinne zapewnia im poczucie bezpieczeństwa i utrzymanie wewnętrznej harmonii.

- Postawa obronna. Charakteryzuje ludzi przesadnie opanowanych. Są sztywni w swych nawykach i przyzwyczajeniach, a także zaabsorbowani pracą zawodową i samowystarczalni. Ich poglądy bywają konwencjonalne, unikają wypowiadania własnego zdania, z trudem mówią o własnych problemach, bardziej zajmują się życiem zewnętrznym niż własnymi przeżyciami. Odczuwają zazwyczaj duży lęk przed śmiercią i niedołęstwem. Zazdroszczą ludziom młodym i wykazują lekkie znerwicowanie.

- Postawa wrogości. Jest znamienna dla agresywnych, podejrzliwych i wybuchowych osób, które mają tendencje do przerzucania na otoczenie własnych pretensji. Cechuje ich brak realizmu oraz traktowanie starości jako ciężkiego okresu wyrzeczeń i ubóstwa, zniedołężnienia i braku sił. Zazdroszczą ludziom młodym, nie potrafią pogodzić się ze starością i boją się śmierci.

- Postawa wrogości skierowana na samego siebie. Jest zwykle manifestowana przez osoby o ujemnym bilansie życiowym. W życiu tych osób było wiele niepowodzeń, dlatego niechętnie wracają do wspomnień życiowych. Są zwykle mało zaradne i nieaktywne, i nie przejawiają buntu przeciwko starości. Brak możliwości zaspokojenia potrzeby miłości jest powodem depresji, pretensji do siebie samych i żalu. Osoby te mają poczucie osamotnienia i zbędności a śmierć traktują jako wyzwolenie od cierpienia.

Miejsce i pozycja człowieka starego w społeczeństwie zmienia się w ciągu wieków. Ludy pierwotne porzucały lub uśmiercały starców, gdy stawali się niedołężni i bezużyteczni. W kulturze starożytnej starcy otaczani byli czcią i szacunkiem, stanowili bowiem skarbnicę wiedzy. Współcześnie człowiek stary postrzegany jest często jako osoba schorowana, niedołężna, uboga, często zaniedbana przez rodzinę. Między ludźmi młodymi a starymi tworzy się dystans międzypokoleniowy. Ludzie starzy są zagubieni we współczesnym świecie i nie nadążają za postępem cywilizacji. Coraz częściej pojawiają się raporty o przemocy wobec ludzi starych. Człowiek stary broni się przed poczuciem, że jest bezużyteczny, i że w całości się zrealizował. Przyjmuje zatem różne role społeczne, które nie pozwalają mu być 
ciężarem dla najbliższych i pozwalają na pomyślne przystosowanie się do starości. Zdają sobie jednak sprawę, iż nie odgrywają już głównej roli na scenie życia. Pozbywają się ciężkich obowiązków, które ciążyły na nich we wcześniejszych etapach życia.

Przejście na emeryturę jest nowym wyzwaniem dla jednostki. Zaangażowanie się w nowe role wypływa z własnej twórczości, a także chęci spełnienia. Jest to warunek pomyślnego procesu starzenia się i zadowolenia ze swego życia.

\section{Możliwości intelektualne ludzi starszych}

Dość powszechny jest stereotyp bazujący na przekonaniu, że możliwości intelektualne ludzi starszych są dużo mniejsze niż ludzi będących na wcześniejszym etapie życia. Stereotyp ten w przekonaniu Zofii Szaroty wynika z badań, które zakorzeniły się głęboko w opinii społecznej, wedle których człowiek po ukończeniu 25 roku życia nie jest w stanie nauczyć się niczego nowego ${ }^{13}$.

Z. Szarota w swojej książce Gerontologia społeczna i oświatowa: zarys problematyki przytacza twierdzenia i wyniki badań osób zajmujących się tą problematyką, które obalają powyższą tezę. I tak przykładowo zdaniem Włodzimierza Szewczuka „możliwości intelektualne człowieka są niezależne od jego wieku metrykalnego i mogą trwać na zadowalającym poziomie aż do końca nawet bardzo długiego życia"14 . Z kolei Józef Rembowski wyraził opinię, iż ograniczenie zdolności uczenia się nie występuje nawet w wieku 6o lat. To, co zdaniem J. Rembowskiego wpływa na spadek możliwości intelektualnych u ludzi starszych nie wynika ze zmian umysłowych, ale raczej powodowane jest zanikiem motywacji, złym stanem zdrowia, czy też ogólną apatią ${ }^{15}$.

Z. Szarota przytoczyła również wyniki badań nad dynamiką ludzkiej inteligencji, które pokazują, że „inteligencja płynna obniża się wraz z wiekiem, jednak jej ubytki są z nadwyżką kompensowane możliwościami wykorzystywania inteligencji skrystalizowanej. Inteligencja skrystalizowana dominuje bowiem w późnym okresie życia nad inteligencją płynną. Umysł nasz dysponuje rezerwami aktywnymi, wykorzystywanymi ad hoc i rezerwami ukrytymi, ujawniającymi się wobec pojawienia się danego problemu lub na przykład w wyniku uczestniczenia osoby starszej w odpowiednich ćwiczeniach. Dorosły intelekt cechuje myślenie dialektyczne oraz relatywizm procesów myślowych. Głównymi cechami inteligencji

\footnotetext{
${ }^{13}$ Por. Z. Szarota, Gerontologia społeczna i oświatowa: zarys problematyki, Kraków 2004, s. 72.

${ }^{14}$ Z. Szarota, Gerontologia społeczna i oświatowa..., dz. cyt., s. 73.

${ }^{15}$ Por. Z. Szarota, Gerontologia społeczna i oświatowa..., dz. cyt., s. 73.
} 
w podeszłym wieku są mądrość płynąca ze zgromadzonego doświadczenia, umiar, rozwaga, spokój, ostrożność kształtujące iście stoicki styl życia"16.

O tym, że możliwości intelektualne osób starszych są nadal duże pokazuje H. C. Lechman, który zauważył, że poeci piszą najlepsze wierze pomiędzy 25. a 29. oraz 80 a 84. rokiem życia; z kolei prozaicy sukces osiągają najczęściej w wieku 3543 lat oraz później między 6o. a 64. rokiem życia; jeśli chodzi natomiast o sztukę plastyczną, to progres występuje pomiędzy 30 a 40. oraz po 70. roku życia artystów, a w przypadku muzyków są to etapy: około 30. roku życia i po ukończeniu 70 lat. Filozofowie z kolei są najbardziej aktywni naukowo między 35. a 40. rokiem życia i po ukończeniu 80 lat $^{17}$.

\section{Postawy pielęgniarek wobec chorych w podeszłym wieku}

Dbałość o pacjenta wynikająca z wrażliwości na cierpienie, to ciągłe poszukiwanie i odkrywanie nowych, lepszych rozwiązań dla osób potrzebujących pomocy, rozpoznawanie indywidualnych potrzeb chorego, a także chronienie ludzkiej godności.

Sensem pielęgniarstwa jest „opiekuńcza troskliwośc”"18. Okres choroby dla człowieka może być czasem na przemyślenia, na które w dotychczasowym życiu nie było możliwości. Okres ten umożliwia zrozumienie, co jest najważniejsze w ludzkim istnieniu oraz umożliwia spojrzenie na wiele trudnych spraw z innej perspektywy. Choroba stwarza sytuacje do innego, a zarazem lepszego przeżywania związków międzyludzkich ${ }^{19}$. Od postawy prezentowanej wobec pacjenta, zależy stosunek pacjenta do choroby i przystosowanie się do nowej, trudnej sytuacji życiowej.

Ważnym zadaniem i wręcz obowiązkiem personelu medycznego jest działanie, dla dobra chorego człowieka, a podstawowymi zasadami są:

- życzliwość,

- nieszkodzenie,

- przestrzeganie zasady autonomii pacjenta.

Pracując z osobą starszą potrzebne jest zrozumienie choroby, jej przyczyn i następstw z punktu widzenia pacjenta. Powinno się informować pacjenta o jego stanie zdrowia i możliwościach leczenia. Pacjent ma prawo sam decydować o podjęciu lub niepodejmowaniu proponowanego sposobu leczenia i zdanie jego powinno

\footnotetext{
${ }^{16}$ Z. Szarota, Gerontologia społeczna i oświatowa..., dz. cyt., s. 73.

17 Por. Z. Szarota, Gerontologia społeczna i oświatowa..., dz. cyt., s. 73-74.

18 Por. K. Osińska, Twórcza obecność chorych, Warszawa 1980, s. 113.

${ }^{19}$ Por. K. Zachradniczek, Pielegniarstwo, Warszawa 2004, s. 74.
} 
być respektowane ${ }^{20}$. Wyzwaniem dla pielęgniarek, poza kompetencją wykonywanych czynności zawodowych, jest umiejętność współdziałania z pacjentem-partnerem, polegająca na „wciąganiu” go do współpracy w czasie terapii i w okresie zdrowienia $^{21}$. Wzajemne zrozumienie wagi problemu i współdziałanie są wyrazem poszanowania godności i autonomii chorego.

Pacjent wymaga kontaktu słownego, powinno się zatrzymać „przy nim”, gdyż cierpienie duszy niekiedy jest trudniejsze do przetrwania niż ból fizyczny ciała ${ }^{22}$.

Pacjenci powinni także przejawiać zainteresowanie swoimi prawami, ponieważ systematyczne egzekwowanie ich przyczyni się do podniesienia jakości świadczonych usług, zmieni podejście do pacjenta z przedmiotowego na podmiotowe. Pielęgniarki w postawach wobec pacjentów powinny kierować się poczuciem odpowiedzialności i przestrzegania zasad zapisanych w kodeksie etyki zawodowej ${ }^{23}$.

Rola współczesnej pielęgniarki w sprawowaniu profesjonalnej opieki nad zdrowiem człowieka podlega ciągłym przemianom, wiąże się to ze zmianami wprowadzanymi w zakresie sprawowanej opieki, jakie nastąpiły w relacji między pacjentem a pielęgniarką i lekarzem. Wykonywanie czynności wymaga od pielęgniarki życzliwości, dodawania choremu wiary i nadziei oraz nauki pozytywnego myślenia.

Podstawowym zadaniem pielęgniarek, jest ochrona zdrowia, ale nigdy pacjent nie może być traktowany jako przypadek kliniczny lub anonimowa jednostka. Człowiek chory powinien być otoczony sympatią i traktowany tak, aby odczuwał, że jest w centrum zainteresowania pracowników ochrony zdrowia.

Decyzja wyboru zawodu pielęgniarki nie powinna być przypadkowa, ponieważ wiąże się ściśle z podjęciem zobowiązania przestrzegania pewnych zasad i wartości moralnych. Należy przy tym pamiętać, że każdy człowiek jest odrębną jednostką ludzką mającą wartość samą w sobie ${ }^{24}$.

Niezmiernie istotny jest poziom reprezentowanych przez pielęgniarkę zasad etycznych, gdyż jest ona osobą mającą ogromny wpływ na pacjenta. Jej postawa ma duży wpływ na niego, jego stosunek do choroby czy cierpienia.

Pielęgniarka to zawód wymagający:

- rzetelności,

- uczciwości,

- odpowiednich cech osobowości,

\footnotetext{
${ }^{20}$ Por. K. Zachradniczek, Pielegniarstwo..., dz. cyt., s. 47-48.

${ }^{21}$ Por. K. Zachradniczek, Pielegniarstwo..., dz. cyt., s. 136.

${ }^{22}$ Por. H. Pera, Sam nie podołam. Sens choroby, sens śmierci, sens życia, Kraków 1984, s. 117.

${ }^{23}$ Por. S. Szatkowski, Etyka i działanie dla dobra chorego, „Postępy rehabilitacji” (200o) nr 4, s. 149.

${ }^{24}$ Por. I. Iżewska, Pacjent - pielegniarka, Warszawa 1981, s. 165.
} 
- świadomej decyzji co do wyboru zawodu,

ponieważ do jego wykonywania nie wystarczy tylko zdobycie odpowiednich kwalifikacji, wiedzy. Dla osoby wykonującej zawód pielęgniarki każdy podopieczny jest równy niezależnie od pozycji ekonomicznej i społecznej, wyznania, rasy lub innych przyczyn. W pracy pielęgniarskiej za fundamentalną zasadę, niezależnie od przedstawianych poglądów filozoficznych, uważa się słowa zawarte w Biblii: „[...] wszystko więc, co byście chcieli, żeby wam ludzie czynili, i wy im czyńcie” (Mt 7-12) ${ }^{25}$.

Pracownicy wykonujący zawody medyczne powinni chronić swoich podopiecznych przed doznaniem krzywdy w sytuacjach, gdy sami nie mogą tego czynić ze względu na wiek, chorobę czy stan umysłu.

Zasada Hipokratesa - primum non nocere, czyli przede wszystkim nie szkodzić. Współczesne normy postępowania pielęgniarek muszą być dostosowane i zgodne ze społecznymi potrzebami. W epoce cywilizacji technicznej i rosnącego braku czynników humanistycznych zalęknieni chorzy oczekują, szczególnie od pielęgniarek będących najbliżej nich, postawy pełnej wyrozumiałości, życzliwości, a ponad wszystko poszanowania godności osobistej. Pacjentowi nie wystarcza tylko świadomość wysokiego poziomu wiedzy personelu i postępu techniki medycznej ${ }^{26}$.

\section{Starzenie się społeczeństwa - wpływ opieki medycznej na długość życia}

Na faktyczną długość i jakość życia ogromny wpływ ma sprawność systemu opieki medycznej i wydajność pracy opieki społecznej. W XXI wieku długość życia zwiększyła się nieporównywalnie bardziej, niż doświadczyła tego ludzkość w przeciągu ponad 2000 lat $^{27}$. Spowodowała to poprawa warunków:

- sanitarnych,

- mieszkaniowych,

- żywieniowych,

- technologii medycznych.

Lepsza opieka medyczna zmniejszyła umieralność dzieci, przyczyniła się do lepszego zdrowia i dłuższego życia również osób zaawansowanych wiekowo. Wydłużenie życia można uznać za triumf nowoczesnego społeczeństwa. Powoduje

\footnotetext{
${ }^{25}$ Por. W. Dyk, Prawa pacjenta a odpowiedzialność prawna pielęgniarki, „Pielęgniarka i Położna” (1998) nr 31.

${ }^{26}$ Por. U. Krzyżanowska-Łagowska, Dylematy etyczne współczesnych pielęgniarek, „Pielęgniarka i Położna” (2001) nr 3.

${ }^{27}$ Por. I. Krzyżanowski, Psychogeriatria, Warszawa 2004, s. 21.
} 
ono ujemne skutki: negatywnie wpływa na rozwój gospodarczy, zatrudnienie, rynki pracy, opiekę zdrowotną i opiekę społeczną.

Potrzebne są działania rozwiązujące problemy związane z finansowaniem zobowiązań emerytur publicznych, brakiem powszechnej dostępności opieki zdrowotnej mogącej spełnić potrzeby rosnącej populacji ludzi starszych. „Od wielu lat obserwuje się rosnący udział osób starszych w konsumowaniu świadczeń placówek opieki zdrowotnej. Rocznie około 70\% ludzi starszych korzysta z ambulatoryjnych porad lekarskich" ${ }^{28}$. Coraz większy postęp w technologii medycznej, wraz ze wzrastającymi oczekiwaniami społecznymi co do opieki i leczenia, gwarantują, że wydatki na opiekę zdrowotną dla wszystkich grup wieku będą rosnąć szybciej niż gospodarka w krajach najbardziej rozwiniętych. Ludzie starsi konsumują trzy do pięciu razy więcej usług medycznych niż ludzie młodsi ${ }^{29}$.

Koszty globalnego starzenia się mogą być tak duże, że wiele krajów może nie dać sobie rady ze zrównoważeniem swoich budżetów. Podwyższanie podatków prawdopodobnie nie będzie rozwiązaniem, które przyniesie poprawę sytuacji. Sugeruje się, żeby w związku z tym opiekę nad starszymi ludźmi sprawowali głównie członkowie rodziny. Zwłaszcza, jeśli potrzebna jest długoterminowa, nieskomplikowana opieka. Starzy ludzie powinni zostawać pod opieką domowników tak długo, jak jest to możliwe. Tylko w przypadku ciężkich, przewlekłych chorób oraz niepełnosprawności rodzina jest zobowiązana skorzystać z profesjonalnej pomocy medycznej dostępnej w szpitalach, domach opieki lub domach starców. Istnieje jednak realne zagrożenie, że takie ustalenia mogłyby wywołać jeszcze większą niechęć do osób starszych i podsycać negatywne nastawienie do nich, kiedy to traktowani są jak ciężar.

Jednym z istotnych problemów pojawiających się przy okazji pojmowania starości w bioetyce jest ustalenie, kiedy właściwie zaczyna się starość człowieka. Medycyna zakłada, że: „z powodu wydłużenia średniego wieku przeżycia populacji i przesunięcia granicy umieralności wśród ludzi w wieku podeszłym wyróżnia się kilka grup wiekowych:

- młodych w wieku między 65-75,

- starych 75-85,

- bardzo starych po 85. roku życia.

Podział ten związany jest zarówno ze zmianami fizjologicznymi, jak i ze zmianami w zakresie funkcjonowania ludzi w wieku podeszłym"30. Kryteria społeczne stosowane w odniesieniu do ludzi po 65. roku życia uwzględniają okres, w którym

\footnotetext{
${ }^{28}$ I. Krzyżanowski, Psychogeriatria..., dz. cyt., s. 28.

${ }^{29}$ Por. I. Krzyżanowski, Psychogeriatria..., dz. cyt., s. 33.

${ }^{30}$ A. Bilikiewicz, Psychiatria podręcznik dla studentów medycyny, PZWL, Warszawa 2004, s. 457.
} 
ludzie starzy funkcjonują niezależnie od systemów pomocy środowiskowej - trzeci wiek, i okres, w którym dominuje uzależnienie od pomocy środowiskowej czwarty wiek. Według Światowej Organizacji Zdrowia początkiem starości demograficznej jest dla obu płci 65. rok życia.

Częstą opinią dotyczącą początku starości wśród samych zainteresowanych, czyli ludzi starych, jest stwierdzenie, że stary jest ten, kto traci zdolność przystosowania się do nowych warunków. Wiek jest więc bardzo ważną zmienną braną pod uwagę przy rozpatrywaniu problemów zdrowotnych, które dotyczą zdrowia fizycznego.

Etyka medyczna nie uporała się z problemem jednoznacznego ustalenia priorytetów w związku z racjonowaniem środków medycznych, zaproponowała jednak pewne sposoby rozwiązania tego problemu.

\section{Proponowana literatura}

Bilikiewicz A., Psychiatria podręcznik dla studentów medycyny, Warszawa 2004.

Dyk W., Prawa pacjenta a odpowiedzialność prawna pielegniarki, „Pielęgniarka i Położna" (1998) nr 31.

Karczmarek S., Rozważania o życiu ludzkim, Warszawa 1997.

Kowalewska A., Jaczewski A., Komosińska A., Problemy wieku starczego, w: Seniorzy w rodzinie, instytucji i społeczeństwie, red. A. Fabiś, Sosnowiec 2005.

Krzyżanowska-Łagowska U., Dylematy etyczne wspótczesnych pielęgniarek, „Pielęgniarka i Położna" (2001) nr 3.

Krzyżanowski I., Psychogeriatria, Warszawa 2004.

Osińska K., Twórcza obecność chorych, Warszawa1980.

Pera H., Sam nie podołam. Sens choroby, sens śmierci, sens życia, Kraków 1984.

Piotrowski J., Miejsce człowieka starego w rodzinie i społeczeństwie, Warszawa 1973.

Rżewska I., Pacjent - pieleggiarka, Warszawa1981.

Szarota Z., Wielofunkcyjna działalność domów pomocy społecznej dla osób starszych, Kraków 1998.

Szatkowski S., Etyka i działanie dla dobra chorego, „Postępy rehabilitacji” (2000).

Szatur-Jaworska B., Ludzie starzy i starość w polityce społecznej, Warszawa 2001.

Wiśniewska-Roszkowska K., Gerontologia dla pracowników socjalnych, Warszawa 1982.

Wiśniewska-Roszkowska K., Starość a przebieg chorób, w: Encyklopedia seniora, Warszawa 1986.

Wolański N., Rozwój biologiczny człowieka, Warszawa 1979.

Zachradniczek K., Pielegniarstwo, Warszawa 2004.

Zych A., Człowiek wobec starości. Szkice z gerontologii społecznej, Katowice 1999. 